\title{
Review Article \\ Honey Mediated Green Synthesis of Nanoparticles: New Era of Safe Nanotechnology
}

\author{
Eranga Roshan Balasooriya, ${ }^{1,2}$ Chanika Dilumi Jayasinghe, \\ Uthpala Apekshani Jayawardena, ${ }^{1,3}$ Ranasinghe Weerakkodige Dulashani Ruwanthika, ${ }^{2}$ \\ Rohini Mendis de Silva, ${ }^{2}$ and Preethi Vidya Udagama ${ }^{1}$
}

\author{
${ }^{1}$ Department of Zoology \& Environment Sciences, Faculty of Science, University of Colombo, Colombo, Sri Lanka \\ ${ }^{2}$ Department of Chemistry, Faculty of Science, University of Colombo, Colombo, Sri Lanka \\ ${ }^{3}$ Department of Zoology, Faculty of Natural Sciences, The Open University of Sri Lanka, Nugegoda, Sri Lanka
}

Correspondence should be addressed to Preethi Vidya Udagama; preethi@zoology.cmb.ac.lk

Received 10 January 2017; Revised 11 February 2017; Accepted 13 February 2017; Published 5 March 2017

Academic Editor: Xuping Sun

Copyright (C) 2017 Eranga Roshan Balasooriya et al. This is an open access article distributed under the Creative Commons Attribution License, which permits unrestricted use, distribution, and reproduction in any medium, provided the original work is properly cited.

\begin{abstract}
With the advent of nanotechnology, many related industries rapidly developed over the recent past. Generally, top-down and bottom-up approaches are the two major processes used to synthesize nanoparticles; most of these require high temperatures, vacuum conditions, and harsh/toxic chemicals. As a consequence, adverse effects impacted organisms including humans. Some synthesis methods are expensive and time-consuming. As a corollary, the concept of "green nanotechnology" emerged with the green synthesis of nanoparticles commencing a new epoch in nanotechnology. This involves the synthesis of nanomaterial from microorganisms, macroorganisms, and other biological materials. Honey is documented as the world's oldest food source with exceptional medical, chemical, physical, and pharmaceutical values. Honey mediated green synthesis is a relatively novel concept used during the past few years to synthesize gold, silver, carbon, platinum, and palladium nanoparticles. Honey acts as both a stabilizing and a reducing agent and importantly functions as a precursor in nanoparticle synthesis. This method usually requires room temperature and does not produce toxic byproducts. In conclusion, honey mediated green synthesis of nanoparticles provides a simple, cost effective, biocompatible, reproducible, rapid, and safe method. The special activity of honey functionalized nanoparticles may provide valuable end products with numerous applications in diverse fields.
\end{abstract}

\section{Introduction}

Over the past decade, nanomaterials emerged as promising commodities in many fields including cosmetics, healthcare, biomedical, food and feed, drug-gene delivery, environment, health, mechanics, optics, chemical industries, electronics, space industries, energy science, catalysis, light emitters, single electron transistors, nonlinear optical devices, and photoelectrochemical applications [1-10].

The theoretical concept of nanotechnology was first described in 1959 by physicist Richard Feynman [11]. Nanotechnology is the ability to understand, control, and manipulate matter at the level of individual atoms and molecules
[12]. The prefix nano is derived from the Greek word nannos. Nanotechnology refers to objects that are sized on a nanometer scale where at least one of the dimensions of a particle must be less than $100 \mathrm{~nm}$. Recent investigations revealed that properties and potential applications of nanoparticles varied with the phases, sizes, and morphologies of these particles $[13,14]$. Thus, controlled synthesis of nanomaterial with novel morphologies has gained much attention.

Synthesis of nanoparticles can be categorized into topdown or bottom-up approaches [15]. Top-down approach involves a process of breaking down of large structures to create small structures. Physical techniques such as lithography [16], laser ablation [17], sputtering deposition [18], 


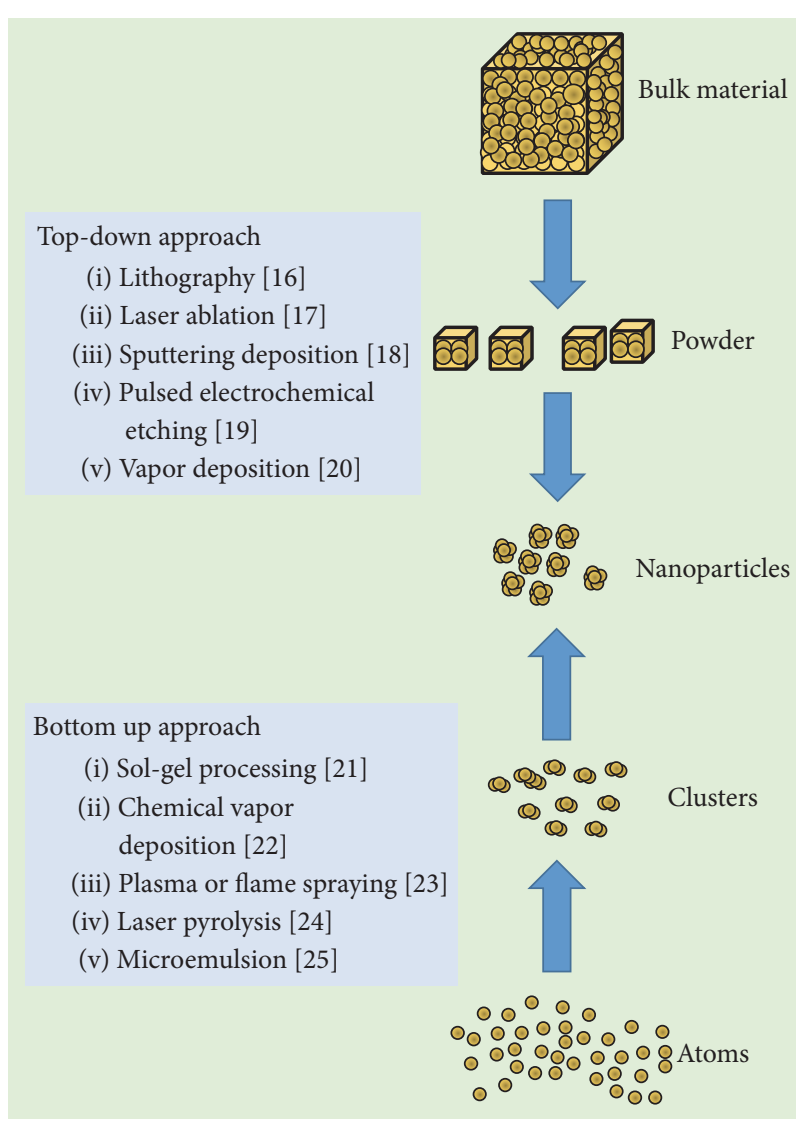

Figure 1: Schematic diagram of currently used chemical and physical methods of nanoparticle synthesis.

pulsed electrochemical etching [19], and vapor deposition [20] are among the most commonly used top-down methods. Bottom-up approaches such as sol-gel processing [21], chemical vapor deposition [22], plasma or flame spraying synthesis [23], laser pyrolysis [24], and microemulsion [25] involve the synthesis of material, atom by atom, molecule by molecule, or cluster by cluster. Figure 1 illustrates different chemical and physical methods of nanoparticle synthesis. Most of these usually require toxic and harsh chemical additives, for example, dimethyl formamide, hydrazine, and sodium borohydride, and physical conditions such as high temperatures, vacuum conditions, and expensive equipment. These methods may result in toxic and harsh products which may pose biological risks to the environment; due to high surface charge and high surface area of nanoparticles, harsh chemicals may remain adsorbed onto nanoparticles. Releasing these chemicals into the environment may cause adverse effects on organisms including microorganisms, plants, invertebrates, and vertebrates including humans at various trophic levels [26]. Therefore, it is essential to optimize green methods for nanoparticle synthesis.

In this review, we initially focus on various methods of green synthesis of nanoparticles. Furthermore, we describe physical and chemical characteristics of natural honey. Thereafter, honey mediated green synthesis of various types of nanoparticles is emphasized. Finally, we highlight the key challenges of green synthesis of nanoparticles.

\section{Green Synthesis}

Recent developments in nanotechnology focus on environmentally friendly, cost effective synthesizing methods. Green synthesis of nanoparticles is an ecofriendly and safe mode of synthesis of nanomaterial using biological resources. This green approach has opened up a new era of safe nanotechnology. Figure 2 compares conventional synthesis methods such as physical and chemical methods with those of green synthesis of nanoparticles. Furthermore, it illustrates the comparison between microorganisms mediated green synthesis and more productive honey mediated green synthesis.

Table 1 lists various methods of green synthesis of nanoparticles and special features manifested by the resultant products. These presently include different approaches such as use of microbial systems, plant systems, and biological methods. Bacteria were used to synthesize several nanoparticles including gold, silver, silver oxide, titanium dioxide, and cadmium sulfide [24-30] while fungi were used to synthesize silver [31-36], titanium dioxide [29], and cadmium sulfide [30]. Furthermore, actinomycetes such as Rhodococcus sp. were used to synthesize gold nanoparticles [25]. Recent experiments revealed the immense potential of algae, particularly in synthesizing silver, gold, zinc oxide, and iron oxide nanoparticles [37-43]. $\mathrm{Au}-\mathrm{Co}_{3} \mathrm{O}_{4}$ nanoparticles were synthesized using a virus mediated method [44]. Moreover, leaf extracts, seed extracts, root extracts, bulbs, and latex of plants were used to synthesize gold, silver, and palladium nanoparticles [45-56]. Biological materials such as honey, starch, and ascorbic acid were used to synthesize gold, silver, palladium, carbon, and platinum nanoparticles [57-63].

\section{Natural Honey}

Natural honey, documented as the world's oldest food source, is an excellent food with high energy and nutritious value [61]. It is produced by Apis mellifera (A. mellifera; honey bee) from plant nectar, secretions, and excretions [67].

Natural honey was applied for medicinal purposes since ancient times. The first evidence of the use of honey as a medication dates back to 2100-2000 BC where a Sumerian tablet contained honey as a drug and an ointment [68]. Furthermore, many animal based studies evidenced the application of honey in cardiovascular diseases, where it affects cardiovascular risk factors such as hyperlipidemia and production of free radicals [69].

\section{Physical Characteristics of Honey}

Natural honey is a sticky and viscous solution, depending on its water content [70]. It also has the ability to absorb and hold moisture from the environment. Normal honey with a water content of $18.8 \%$ or less will absorb moisture from air of a relative humidity of above $60 \%$ [71].

The color of liquid honey varies from clear and colorless (alike water) to dark amber or black. The color of honey 


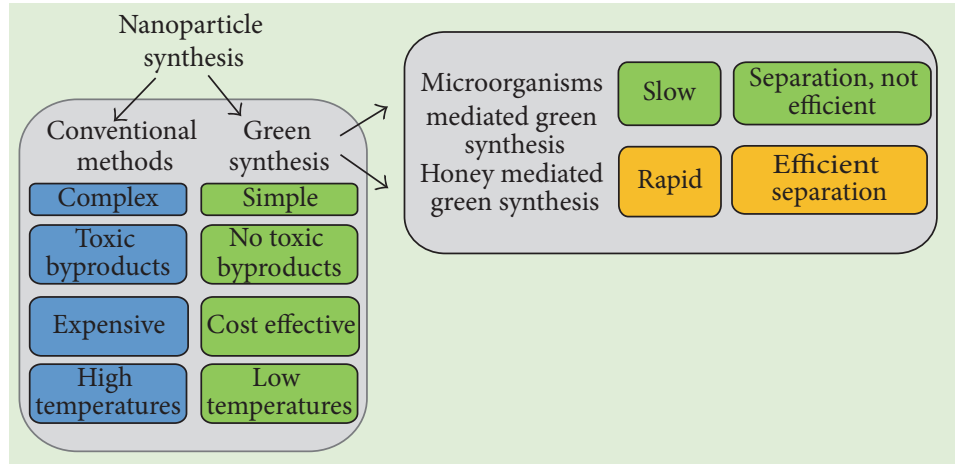

FIGURE 2: Comparison of conventional methods and green synthesis methods of nanoparticle synthesis.

appears in all shades of yellow and amber; color varies with botanical origin, age, and storage conditions, but transparency or clarity depends upon the amount of suspended particles such as pollens [72].

\section{Chemical Composition of Honey}

Honey is one of the healthiest food sources since immemorial time. It consists of $80-85 \%$ carbohydrate (mainly glucose and fructose), $15-17 \%$ water, $0.1-0.4 \%$ protein, $0.2 \%$ ash, and minor quantities of amino acids, enzymes, and vitamins as well as other substances such as phenolic antioxidants. However, the precise chemical composition and physical properties of natural honey differ according to the plant species on which the bees foraged, differences in climatic conditions, and vegetation [70].

Fructose (32.56 to $38.2 \%$ ) and glucose (28.54 to $31.3 \%$ ) as the major carbohydrates present in honey represent $85-95 \%$ of total sugars and are readily absorbed in the gastrointestinal tract. Other sugars include disaccharides such as maltose, sucrose, isomaltose, turanose, nigerose, melibiose, panose, maltotriose, and melezitose. A few oligosaccharides are also present. Honey contains 4 to $5 \%$ fructooligosaccharides, which serve as probiotic agents [73].

Honey contains proteins in $0.1-0.5 \%$ quantities, which differ greatly with types and origin of honey [70]. Natural honey is also rich in vitamins such as $\mathrm{C}$ and $\mathrm{B}_{1}$ (thiamine) and $\mathrm{B}_{2}$ complex vitamins including riboflavin, nicotinic acid, $\mathrm{B}_{6}$, and pantothenic acid [74].

Almost all natural honey varieties contain flavonoids (apigenin, pinocembrin, kaempferol, quercetin, galangin, chrysin, and hesperetin), phenolic compounds (ellagic, caffeic, and p-coumaric and ferulic acids), and bioactive compounds such as ascorbic acid, tocopherols, catalase (CAT), superoxide dismutase (SOD), and reduced glutathione (GSH) as antioxidant enzymes [75].

The concentration of mineral compounds ranges from $0.1 \%$ to $1.0 \%$. Potassium is the major metal, followed by calcium, magnesium, sodium, sulphur, and phosphorus. Trace elements include iron, copper, zinc, and manganese [76].

A variety of enzymes, for example, oxidase, invertase, amylase, and catalase, are constituents of honey; the main enzymes are invertase (saccharase), diastase (amylase), and glucose oxidase. Dextrin and maltose are produced from long starch chains by the activity of amylase enzyme [70]. Each of these minor constituents is known to have distinctive nutritional or medicinal properties and the unique blend accounts for the varied and different applications of natural honey.

\section{Honey Mediated Green Synthesis of Nanoparticles}

Special chemical properties of honey render its usage in green synthesis of nanoparticles. As a consequence, honey mediated synthesis offers several advantages over the microorganism mediated methods; it is relatively a rapid process compared to the microbial method. Also, microorganisms must be cultured with extreme care and there is a time lag for the conversion of nanoparticles by microorganisms. Furthermore, separation of nanoparticles from microorganisms can be a difficult task.

Based on literature [77], Figure 3 illustrates the proposed mechanism and Table 2 lists the reducing and stabilizing agents and specific temperatures used in honey mediated biosynthesis of different nanoparticles. While the generalized procedure was used for gold, silver, and palladium nanoparticles, carbon and platinum nanoparticles had utilized specific conditions.

\section{Gold Nanoparticles}

Philip synthesized gold nanoparticles by reducing $\mathrm{HAuCl}_{4}$ with different volumes of diluted honey where the reduction speed of gold particles increased with the increasing volume of honey [55]. Accordingly, fructose as the primary ingredient of honey may have acted as the prime reducing agent collectively with vitamin $\mathrm{C}$, that is, a mild reducing agent. Furthermore, he postulated that this reduction may be facilitated by the presence of $\mathrm{H}_{2} \mathrm{O}_{2}$ and gluconic acid, produced when diluting honey with distilled water. Fructose is claimed as the possible reducing agent for the reaction while proteins present in honey were responsible for the stabilization of the nanoparticles [61].

Olaitan and colleagues reported green synthesis of gold nanoparticles at room temperature using honey as both a 
TABLE 1: Different methods of green synthesis of nanoparticles, relevant organisms, and special characteristics of synthesized nanoparticles.

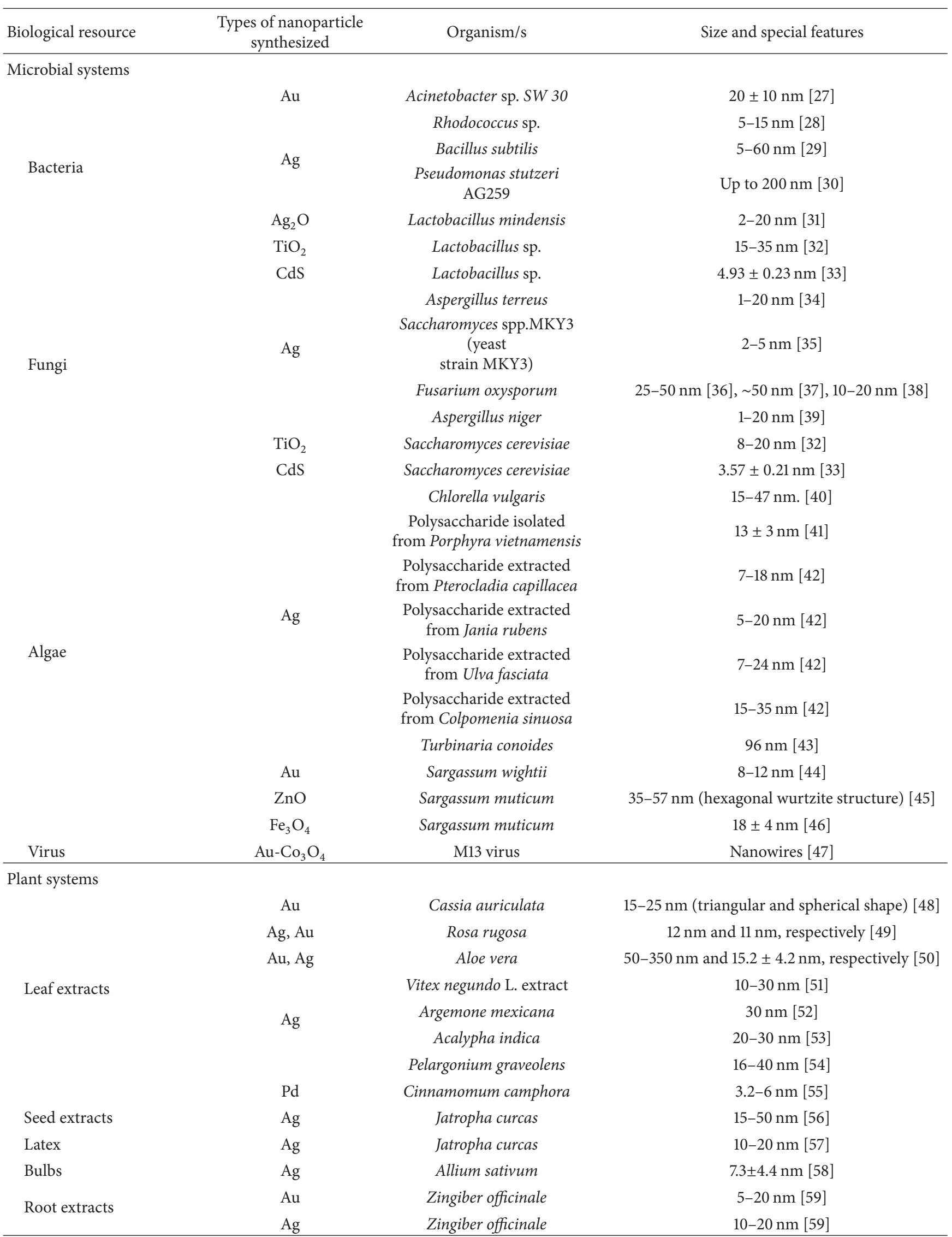


TABLE 1: Continued.

\begin{tabular}{|c|c|c|c|}
\hline Biological resource & $\begin{array}{c}\text { Types of nanoparticle } \\
\text { synthesized }\end{array}$ & Organism/s & Size and special features \\
\hline \multicolumn{4}{|l|}{ Biological material } \\
\hline Ascorbic acid and starch & $\mathrm{Ag}$ & - & $17-30 \mathrm{~nm}$ (truncated triangle nanoplates) [60] \\
\hline \multirow{5}{*}{ Honey } & $\mathrm{Au}$ & - & $\sim 15 \mathrm{~nm}[61]$ \\
\hline & $\mathrm{Ag}$ & - & $18.98-26.05 \mathrm{~nm}[62]$ \\
\hline & $\mathrm{Pd}$ & - & $5-40 \mathrm{~nm}[63]$ \\
\hline & $\mathrm{Pt}$ & - & $2.2 \mathrm{~nm}[64]$ \\
\hline & $\mathrm{C}$ & - & $\sim 7 \mathrm{~nm}[65]$ \\
\hline Starch & $\mathrm{Ag}$ & - & $10-34 \mathrm{~nm}[66]$ \\
\hline
\end{tabular}

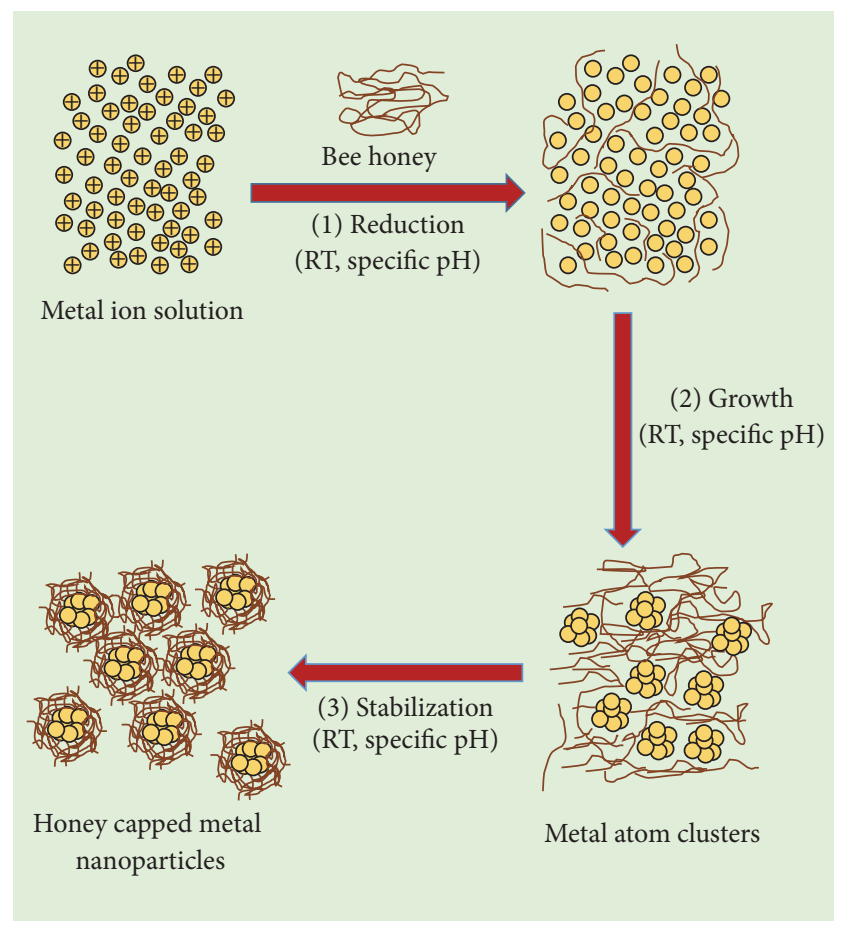

FIGURE 3: Generalized schematic diagram of honey mediated green synthesis of nanoparticles; proposed mechanism [77].

reducing and a stabilizing agent [71]. Consequently, a $9.9 \pm$ $3.7 \mathrm{~nm}$ particle size was observed by transmission electron microscopy (TEM) that manifested moderate antibacterial activity against both gram positive and gram negative bacterial strains. The lowest minimum inhibitory concentration (MIC) was reported against Staphylococcus aureus at $31.25 \mathrm{~g} / \mathrm{mL}[78]$.

\section{Silver Nanoparticles}

Bar and colleagues synthesized silver nanoparticles using honey at room temperature, where honey acted as both a reducing and a stabilizing agent [56]. Thus, it replaced toxic and harsh reducing agents such as dimethyl formamide, hydrazine, and sodium borohydride used previously. Synthesized nanoparticles were stable for five months without any
TABLE 2: Reducing and stabilizing agents and specific temperatures used in honey mediated biosynthesis of different nanoparticles.

\begin{tabular}{llll}
\hline $\begin{array}{l}\text { Nanoparticle } \\
\text { type }\end{array}$ & Reducing agent & $\begin{array}{l}\text { Stabilization } \\
\text { agent }\end{array}$ & $\begin{array}{l}\text { Specific } \\
\text { temperature }\end{array}$ \\
\hline Gold & $\begin{array}{l}\text { (i) Vitamin } \mathrm{C} \\
\text { (ii) } \mathrm{H}_{2} \mathrm{O}_{2} \text { and } \\
\text { gluconic acid, } \\
\text { produced when } \\
\text { diluting honey } \\
\text { with distilled } \\
\text { water [61] }\end{array}$ & $\begin{array}{l}\text { Proteins } \\
\text { present in } \\
\text { honey }\end{array}$ & RT $[61,78]$ \\
& Honey & $\begin{array}{l}\text { Proteins in } \\
\text { honey [79] }\end{array}$ & $\begin{array}{l}\text { RT } \\
{[62,78-80]}\end{array}$ \\
Silver & Honey & $\begin{array}{l}\text { Honey } \\
\text { Proteins in }\end{array}$ & RT [63] \\
Palladium & Honey & honey $[64]$ \\
Platinum & Honey &
\end{tabular}

stabilizer. The size and morphology of silver nanoparticles were dependent upon the concentration of honey used and the $\mathrm{pH}$, where particle size decreased with increasing $\mathrm{pH}$. Moreover, scanning electron microscopy (SEM) studies revealed an inverse correlation between size of the silver nanoparticles and the honey concentration; size of the silver nanoparticles was in the range of $18.98-26.05 \mathrm{~nm}$, when $10 \mathrm{~g}$ of honey was used, while the size further reduced to 15.63$17.86 \mathrm{~nm}$ range with increased honey concentration up to $40 \mathrm{~g}$ [62].

A sunlight mediated method to synthesize Ag nanoparticles using honey as both a reducing and a stabilization agent was reported [72]. These honey capped silver nanoparticles were effective corrosion inhibitors for mild steel and remained stable at room temperature for more than six months. Proteins in honey seemed to be the capping agent which stabilized the nanoparticles while fructose acted as the reducing agent [79].

Nearly spherical and monodispersed silver nanoparticles were synthesized with the size of $\sim 4 \mathrm{~nm}$ at $\mathrm{pH}$ of 8.5 at room temperature [73]. The resultant silver nanoparticles were synthesized in various sizes by adjusting the $\mathrm{pH}$ of the solution by using honey as the reducing and stabilization agent. TEM studies and X-ray diffraction (XRD) studies showed a high crystalline and face-centered cubic (fcc) structure. XRD patterns corresponded to (1 111$),\left(\begin{array}{lll}2 & 0 & 0\end{array}\right),\left(\begin{array}{lll}2 & 2 & 0\end{array}\right),\left(\begin{array}{lll}3 & 1 & 1\end{array}\right)$, 
and (2 2 2) planes. Furthermore, Fourier Transform Infrared Spectroscopy (FT-IR) spectrum indicated that the proteins were bound to silver nanoparticles through the carboxylate group [80]. Furthermore, silver nanoparticles with $11.9 \pm$ $5.25 \mathrm{~nm}$ particle size were synthesized at room temperature using honey as both reducing and stabilizing agents. These nanoparticles demonstrated significant antimicrobial activity against a wide range of bacterial and fungal strains. The lowest minimum inhibitory concentration (MIC) was demonstrated against Staphylococcus aureus at $2.81 \mathrm{~g} / \mathrm{mL}$ [78].

\section{Palladium Nanoparticles}

Pd nanoparticles with the range of 5 to $40 \mathrm{~nm}$ were synthesized using honey as both reducing and stabilizing agents [63]. This nanocatalyst showed higher reusability; Pd nanoparticles were used as a catalyst for Suzuki crosscoupling and in the hydrogenation of conjugated olefins. Thus, honey coated Pd nanoparticles possess potential applications in different fields including nanobiotechnology, organic catalytic transformation, and sensors [63].

\section{Carbon Nanoparticles}

In the green synthesis of nanomaterial, honey is commonly used as both a stabilizer and a reducing agent. Wu and colleges, however, used honey as a precursor in synthesizing carbon nanoparticles for real time photoacoustic imaging [65]. These surface coated polysorbate and polyethyleneglycol C nanoparticles were comparatively smaller $(\sim 7 \mathrm{~nm})$ than the previously used particles such as silica coated gold nanoparticles $(20 \mathrm{~nm})$ [81], single wall nanotubes (SWNT), and $\mathrm{Cu}$, used for sentinel lymph node (SLN) imaging. Authors claimed a rapid signal enhancement ( $\sim 2 \mathrm{~min})$ with these carbon nanoparticles [65].

Two nm high-fluorescent carbon dots were synthesized from honey for sensing and imaging with a quantum yield (QY) of approximately $19.8 \%$ [82]. Green synthesized carbon dots exhibited higher stability with other advantages including nontoxicity, high-fluorescent quantum yield, and photostability. Moreover, these carbon dots were used as a sensor for the detection of $\mathrm{Fe}^{3+}$ and were applied for fluorescent staining and cell imaging. Authors suggest many potential applications of carbon dots in biosensing and bioimaging [82].

\section{Platinum Nanoparticles}

Venu and colleges reported a honey mediated, novel, economically feasible method to synthesize platinum nanoparticles and nanowires [64]. They synthesized $2.2 \mathrm{~nm}$ sized Pt nanoparticles at $100^{\circ} \mathrm{C}$ in aqueous honey solution and, furthermore, 5-15 $\mathrm{nm}$ length platinum nanowires formed with longer thermal treatment by self-assembly. Characterization of the resultant nanoparticles by spectroscopic, morphological, and structural studies suggests that honey played an important role in the reduction of platinum nanoparticles. Furthermore, honey functionalized platinum nanoparticles were highly crystalline and the structure was a face-centered

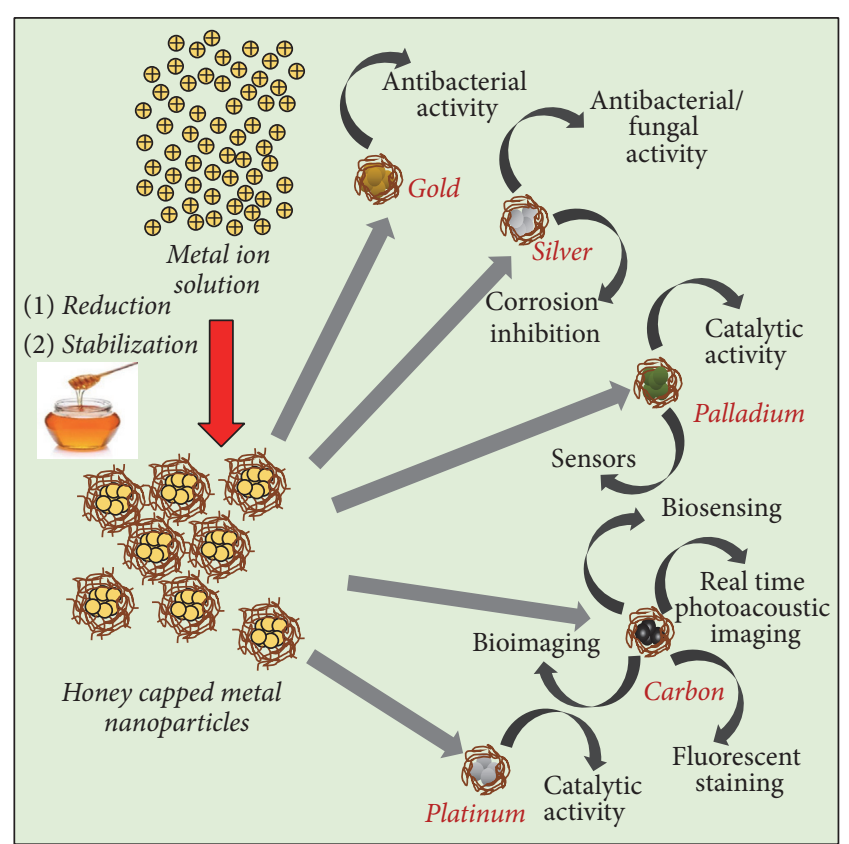

FIgURE 4: Schematic diagram of various current applications of honey mediated green synthesis of nanoparticles [63, 64, 78, 79, 82].

cubic. FT-IR analysis suggested that the proteins were bound to platinum nanoparticles through the carboxylate group. These nanoparticles were stable in water for more than four months and showed catalytic properties for the formation of antipyrilquinoneimine dye from 4-aminoantipyrine and aniline in an acidic aqueous medium. Venu et al. posited the application of this catalytic property in the detection and removal of anilines from soil and water samples [64].

Figure 4 illustrates the numerous current applications of honey mediated green synthesis of gold, silver, palladium, carbon, and platinum nanoparticles. Honey mediated green synthesized gold and silver nanoparticles can be used as potent antibacterial agents [78]. Furthermore, silver nanoparticles show antifungal activity and anticorrosion activity [79]. Palladium nanoparticles show catalytic activity and can be used in sensor related applications [63]. Honey synthesized carbon nanoparticles are used in many areas including biosensing, bioimaging, fluorescent staining, and real time photoacoustic imaging [82]. Platinum nanoparticles show catalytic activity [64].

\section{Challenges}

Honey mediated green synthesis of nanoparticles is a novel concept and yet remains to be fully developed and established. To date, a limited number of studies were conducted, restricted to the synthesis of metallic and carbon nanoparticles. It is essential to synthesize monodispersed nanoparticles to obtain maximum usage. Methods must be optimized to synthesize other complex nanoparticles such as $\mathrm{Fe}_{3} \mathrm{O}_{2}, \mathrm{TiO}_{2}$, $\mathrm{ZnO}$, and $\mathrm{CdS}$. Further studies are warranted to identify the actual ingredients that are responsible for the reduction of metal ions. In some studies, FT-IR spectrum revealed 
that proteins were responsible for the stabilization. However, further studies are crucial to identify the relevant proteins responsible for the functionalization of these nanoparticles.

\section{Conclusion}

Most common nanoparticle synthesis methods frequently use harsh chemicals such as hydrazine, dimethylformamide, and sodium borohydride and high temperatures which may pose biological hazards to the environment. On the contrary, honey mediated green synthesis requires relatively low temperatures (generally room temperature) and does not produce any toxic products. Green synthesis methods can be used as an alternative for the currently used chemical and physical synthesis methods. Furthermore, green synthesis of nanoparticles using honey mediated methods demonstrated ecofriendly, cost effective, time saving, and easy processing methods, where honey acted as both reducing and stabilizing agents. Honey functionalized nanoparticles express special activities such as catalytic properties, anticorrosive activities, antimicrobial activity, and biosensing and bioimaging ability. With further improvement, nanoparticles synthesized by honey mediated green methods may provide potential and valuable end products with numerous applications in many fields providing a superior, ecofriendly alternative for harsh and toxic procedures, practiced to date.

\section{Abbreviations \\ TEM: Transmission electron microscope \\ MIC: Minimum inhibitory concentration \\ SEM: Scanning electron microscope \\ XRD: X-ray diffraction \\ FCC: Face-centered cubic \\ FT-IR: Fourier Transform Infrared Spectroscopy \\ SLN: Sentinel lymph nodes \\ QY: Quantum yield \\ UV: Ultraviolet.}

\section{Competing Interests}

The authors declare that they have no competing interests.

\section{Acknowledgments}

Departments of Zoology \& Environment Sciences and Chemistry, Faculty of Science, University of Colombo, Sri Lanka, are thankfully acknowledged for providing a platform to compile this review.

\section{References}

[1] J. Bakó, F. Kerényi, E. Hrubi et al., "Poly- $\gamma$-glutamic acid nanoparticles based visible light-curable hydrogel for biomedical application," Journal of Nanomaterials, vol. 2016, Article ID 7350516, 10 pages, 2016.

[2] L. Chen, X.-F. Jiang, Z. Guo et al., “Tuning optical nonlinearity of laser-ablation-synthesized silicon nanoparticles via doping concentration," Journal of Nanomaterials, vol. 2014, Article ID 652829, 7 pages, 2014.
[3] D. Itohara, K. Shinohara, T. Yoshida, and Y. Fujita, "p-channel and $\mathrm{n}$-channel thin-film-transistor operation on sprayed $\mathrm{ZnO}$ nanoparticle layers," Journal of Nanomaterials, vol. 2016, Article ID 8219326, 6 pages, 2016.

[4] A. Lohani, A. Verma, H. Joshi, N. Yadav, and N. Karki, "Nanotechnology-based cosmeceuticals," ISRN Dermatology, vol. 2014, Article ID 843687, 14 pages, 2014.

[5] H. Pei, S. Zhu, M. Yang, R. Kong, Y. Zheng, and F. Qu, "Graphene oxide quantum dots@silver core-shell nanocrystals as turn-on fluorescent nanoprobe for ultrasensitive detection of prostate specific antigen," Biosensors and Bioelectronics, vol. 74, pp. 909-914, 2015.

[6] K. Sreejivungsa, N. Suchaichit, P. Moosophon, and A. Chompoosor, "Light-regulated release of entrapped drugs from photoresponsive gold nanoparticles," Journal of Nanomaterials, vol. 2016, Article ID 4964693, 7 pages, 2016.

[7] J. Yuan, Y. Cen, X.-J. Kong et al., " $\mathrm{MnO}_{2}$-nanosheet-modified upconversion nanosystem for sensitive turn-on fluorescence detection of $\mathrm{H}_{2} \mathrm{O}_{2}$ and glucose in blood," ACS Applied Materials and Interfaces, vol. 7, no. 19, pp. 10548-10555, 2015.

[8] P. Zhang, R. Wei, J. Zeng, M. Cai, J. Xiao, and D. Yang, “Thermal properties of silver nanoparticle sintering bonding paste for high-power led packaging," Journal of Nanomaterials, vol. 2016, Article ID 8681513, 6 pages, 2016.

[9] Y. Zhao, Y. Yeh, R. Liu, J. You, and F. Qu, "Facile deposition of gold nanoparticles on core-shell $\mathrm{Fe}_{3} \mathrm{O}_{4} @$ polydopamine as recyclable nanocatalyst," Solid State Sciences, vol. 45, article 5125, pp. 9-14, 2015.

[10] Y. Zhao, Y. Zheng, C. Zhao, J. You, and F. Qu, "Hollow PDA-Au nanoparticles-enabled signal amplification for sensitive nonenzymatic colorimetric immunodetection of carbohydrate antigen 125," Biosensors and Bioelectronics, vol. 71, pp. 200-206, 2015.

[11] D. Bhattacharyya, S. Singh, and N. Satnalika, "Nanotechnology, big things from a tiny world: a review," International Journal of $u$ - and e-Service, Science and Technology, vol. 2, no. 3, pp. 29-38, 2009.

[12] W. A. Goddard III, D. Brenner, S. E. Lyshevski, and G. J. Iafrate, Handbook of Nanoscience, Engineering, and Technology, CRC Press, 2nd edition, 2007.

[13] M.-C. Daniel and D. Astruc, "Gold nanoparticles: assembly, supramolecular chemistry, quantum-size-related properties, and applications toward biology, catalysis, and nanotechnology," Chemical Reviews, vol. 104, no. 1, pp. 293-346, 2004.

[14] H. D. Jang, S.-K. Kim, and S.-J. Kim, "Effect of particle size and phase composition of titanium dioxide nanoparticles on the photocatalytic properties," Journal of Nanoparticle Research, vol. 3, no. 2-3, pp. 141-147, 2001.

[15] C. J. Murphy, "Materials science: nanocubes and nanoboxes," Science, vol. 298, no. 5601, pp. 2139-2141, 2002.

[16] L. Tapasztó, G. Dobrik, P. Lambin, and L. P. Biró, “Tailoring the atomic structure of graphene nanoribbons by scanning tunnelling microscope lithography," Nature Nanotechnology, vol. 3, no. 7, pp. 397-401, 2008.

[17] S. Barcikowski, F. Devesa, and K. Moldenhauer, "Impact and structure of literature on nanoparticle generation by laser ablation in liquids," Journal of Nanoparticle Research, vol. 11, no. 8, pp. 1883-1893, 2009.

[18] J. Bell, Z. Chen, and A. Olofinjana, "Synthesis of amorphous carbon nitride using reactive ion beam sputtering deposition with grazing bombardment," Diamond and Related Materials, vol. 10, no. 12, pp. 2184-2189, 2001. 
[19] T. Nissinen, T. Ikonen, M. Lama, J. Riikonen, and V.-P. Lehto, "Improved production efficiency of mesoporous silicon nanoparticles by pulsed electrochemical etching," Powder Technology, vol. 288, pp. 360-365, 2016.

[20] M. Kumar and Y. Ando, "Chemical vapor deposition of carbon nanotubes: a review on growth mechanism and mass production," Journal of Nanoscience and Nanotechnology, vol. 10, no. 6, pp. 3739-3758, 2010.

[21] G. Yi, Z. Wu, and M. Sayer, "Preparation of $\mathrm{Pb}(\mathrm{Zr}, \mathrm{Ti}) \mathrm{O}_{3}$ thin films by sol gel processing: electrical, optical, and electro-optic properties," Journal of Applied Physics, vol. 64, no. 5, pp. 27172724, 1988.

[22] Y.-L. Li, I. A. Kinloch, and A. H. Windle, "Direct spinning of carbon nanotube fibers from chemical vapor deposition synthesis," Science, vol. 304, no. 5668, pp. 276-278, 2004.

[23] L. Mädler, H. K. Kammler, R. Mueller, and S. E. Pratsinis, "Controlled synthesis of nanostructured particles by flame spray pyrolysis," Journal of Aerosol Science, vol. 33, no. 2, pp. 369-389, 2002.

[24] F. Lacour, O. Guillois, X. Portier, H. Perez, N. Herlin, and C. Reynaud, "Laser pyrolysis synthesis and characterization of luminescent silicon nanocrystals," Physica E: Low-Dimensional Systems and Nanostructures, vol. 38, no. 1-2, pp. 11-15, 2007.

[25] M. Darbandi, R. Thomann, and T. Nann, "Single quantum dots in silica spheres by microemulsion synthesis," Chemistry of Materials, vol. 17, no. 23, pp. 5720-5725, 2005.

[26] S. Rana and P. T. Kalaichelvan, "Ecotoxicity of nanoparticles," ISRN Toxicology, vol. 2013, Article ID 574648, 11 pages, 2013.

[27] S. A. Wadhwani, U. U. Shedbalkar, R. Singh, M. S. Karve, and B. A. Chopade, "Novel polyhedral gold nanoparticles: green synthesis, optimization and characterization by environmental isolate of Acinetobacter sp. SW30," World Journal of Microbiology and Biotechnology, vol. 30, no. 10, pp. 2723-2731, 2014.

[28] A. Ahmad, S. Senapati, M. I. Khan et al., "Intracellular synthesis of gold nanoparticles by a novel alkalotolerant actinomycete, Rhodococcus species," Nanotechnology, vol. 14, no. 7, pp. 824828, 2003.

[29] N. Saifuddin, C. W. Wong, and A. A. N. Yasumira, "Rapid biosynthesis of silver nanoparticles using culture supernatant of bacteria with microwave irradiation," E-Journal of Chemistry, vol. 6, no. 1, pp. 61-70, 2009.

[30] T. Klaus, R. Joerger, E. Olsson, and C. Granqvist, "Silver-based crystalline nanoparticles, microbially fabricated," Proceedings of the National Academy of Sciences, vol. 96, no. 24, pp. 13611-13614, 1999.

[31] Z. H. Dhoondia and H. Chakraborty, "Lactobacillus mediated synthesis of silver oxide nanoparticles," Nanomaterials and Nanotechnology, vol. 2, 2012.

[32] A. K. Jha, K. Prasad, and A. R. Kulkarni, "Synthesis of $\mathrm{TiO}_{2}$ nanoparticles using microorganisms," Colloids and Surfaces B: Biointerfaces, vol. 71, no. 2, pp. 226-229, 2009.

[33] K. Prasad and A. K. Jha, "Biosynthesis of CdS nanoparticles: an improved green and rapid procedure," Journal of Colloid and Interface Science, vol. 342, no. 1, pp. 68-72, 2010.

[34] G. Li, D. He, Y. Qian et al., "Fungus-mediated green synthesis of silver nanoparticles using Aspergillus terreus," International Journal of Molecular Sciences, vol. 13, no. 1, pp. 466-476, 2012.

[35] M. Kowshik, S. Ashtaputre, S. Kharrazi et al., "Extracellular synthesis of silver nanoparticles by a silver-tolerant yeast strain MKY3," Nanotechnology, vol. 14, no. 1, pp. 95-100, 2003.
[36] H. Korbekandi, Z. Ashari, S. Iravani, and S. Abbasi, "Optimization of biological synthesis of silver nanoparticles using Fusarium oxysporum," Iranian Journal of Pharmaceutical Research, vol. 12, no. 3, pp. 289-298, 2013.

[37] M. Gholami-Shabani, A. Akbarzadeh, D. Norouzian et al., "Antimicrobial activity and physical characterization of silver nanoparticles green synthesized using nitrate reductase from Fusarium oxysporum," Applied Biochemistry and Biotechnology, vol. 172, no. 8, pp. 4084-4098, 2014.

[38] S. S. Birla, S. C. Gaikwad, A. K. Gade, and M. K. Rai, "Rapid synthesis of silver nanoparticles from fusarium oxysporum by optimizing physicocultural conditions," The Scientific World Journal, vol. 2013, Article ID 796018, 12 pages, 2013.

[39] G. Sagar and B. Ashok, "Green synthesis of silver nanoparticles using Aspergillus niger and its efficacy against human pathogens," European Journal of Experimental Biology, vol. 2, pp. 1654-1658, 2012.

[40] J. Annamalai and T. Nallamuthu, "Green synthesis of silver nanoparticles: characterization and determination of antibacterial potency," Applied Nanoscience, vol. 6, no. 2, pp. 259-265, 2016.

[41] V. Venkatpurwar and V. Pokharkar, "Green synthesis of silver nanoparticles using marine polysaccharide: study of in-vitro antibacterial activity," Materials Letters, vol. 65, no. 6, pp. 9991002, 2011.

[42] H. M. El-Rafie, M. H. El-Rafie, and M. K. Zahran, "Green synthesis of silver nanoparticles using polysaccharides extracted from marine macro algae," Carbohydrate Polymers, vol. 96, no. 2, pp. 403-410, 2013.

[43] S. Rajeshkumar, C. Kannan, and G. Annadurai, "Green synthesis of silver nanoparticles using marine brown Algae turbinaria conoides and its antibacterial activity," International Journal of Pharma and Bio Sciences, vol. 3, no. 4, pp. 502-510, 2012.

[44] G. Singaravelu, J. S. Arockiamary, V. G. Kumar, and K. Govindaraju, "A novel extracellular synthesis of monodisperse gold nanoparticles using marine alga, Sargassum wightii Greville," Colloids and Surfaces B: Biointerfaces, vol. 57, no. 1, pp. 97-101, 2007.

[45] S. Azizi, M. B. Ahmad, F. Namvar, and R. Mohamad, "Green biosynthesis and characterization of zinc oxide nanoparticles using brown marine macroalga Sargassum muticum aqueous extract," Materials Letters, vol. 116, pp. 275-277, 2014.

[46] M. Mahdavi, F. Namvar, M. B. Ahmad, and R. Mohamad, "Green biosynthesis and characterization of magnetic iron oxide $\left(\mathrm{Fe}_{3} \mathrm{O}_{4}\right)$ nanoparticles using seaweed (Sargassum muticum) aqueous extract," Molecules, vol. 18, no. 5, pp. 5954-5964, 2013.

[47] K. T. Nam, D.-W. Kim, P. J. Yoo et al., "Virus-enabled synthesis and assembly of nanowires for lithium ion battery electrodes," Science, vol. 312, no. 5775, pp. 885-888, 2006.

[48] V. Ganesh Kumar, S. Dinesh Gokavarapu, A. Rajeswari et al., "Facile green synthesis of gold nanoparticles using leaf extract of antidiabetic potent Cassia auriculata," Colloids and Surfaces B: Biointerfaces, vol. 87, no. 1, pp. 159-163, 2011.

[49] S. P. Dubey, M. Lahtinen, and M. Sillanpää, "Green synthesis and characterizations of silver and gold nanoparticles using leaf extract of Rosa rugosa," Colloids and Surfaces A: Physicochemical and Engineering Aspects, vol. 364, no. 1-3, pp. 34-41, 2010.

[50] S. P. Chandran, M. Chaudhary, R. Pasricha, A. Ahmad, and M. Sastry, "Synthesis of gold nanotriangles and silver nanoparticles using Aloe vera plant extract," Biotechnology Progress, vol. 22, no. 2, pp. 577-583, 2006. 
[51] M. Zargar, A. A. Hamid, F. A. Bakar et al., "Green synthesis and antibacterial effect of silver nanoparticles using Vitex negundo L.," Molecules, vol. 16, no. 8, pp. 6667-6676, 2011.

[52] A. Singh, D. Jain, M. K. Upadhyay, N. Khandelwal, and H. N. Verma, "Green synthesis of silver nanoparticles using Argemone Mexicana leaf extract and evaluation of their antimicrobial activities," Digest Journal of Nanomaterials and Biostructures, vol. 5, no. 2, pp. 483-489, 2010.

[53] C. Krishnaraj, E. G. Jagan, S. Rajasekar, P. Selvakumar, P. T. Kalaichelvan, and N. Mohan, "Synthesis of silver nanoparticles using Acalypha indica leaf extracts and its antibacterial activity against water borne pathogens," Colloids and Surfaces B: Biointerfaces, vol. 76, no. 1, pp. 50-56, 2010.

[54] S. S. Shankar, A. Ahmad, and M. Sastry, "Geranium leaf assisted biosynthesis of silver nanoparticles," Biotechnology Progress, vol. 19, no. 6, pp. 1627-1631, 2003.

[55] X. Yang, Q. Li, H. Wang et al., "Green synthesis of palladium nanoparticles using broth of Cinnamomum camphora leaf," Journal of Nanoparticle Research, vol. 12, no. 5, pp. 1589-1598, 2010.

[56] H. Bar, D. K. Bhui, G. P. Sahoo, P. Sarkar, S. Pyne, and A. Misra, "Green synthesis of silver nanoparticles using seed extract of Jatropha curcas," Colloids and Surfaces A: Physicochemical and Engineering Aspects, vol. 348, no. 1-3, pp. 212-216, 2009.

[57] H. Bar, D. K. Bhui, G. P. Sahoo, P. Sarkar, S. P. De, and A. Misra, "Green synthesis of silver nanoparticles using latex of Jatropha curcas," Colloids and Surfaces A: Physicochemical and Engineering Aspects, vol. 339, no. 1-3, pp. 134-139, 2009.

[58] L. Rastogi and J. Arunachalam, "Sunlight based irradiation strategy for rapid green synthesis of highly stable silver nanoparticles using aqueous garlic (Allium sativum) extract and their antibacterial potential," Materials Chemistry and Physics, vol. 129, no. 1-2, pp. 558-563, 2011.

[59] P. Velmurugan, K. Anbalagan, M. Manosathyadevan et al., "Green synthesis of silver and gold nanoparticles using Zingiber officinale root extract and antibacterial activity of silver nanoparticles against food pathogens," Bioprocess and Biosystems Engineering, vol. 37, no. 10, pp. 1935-1943, 2014.

[60] Z. Khan, T. Singh, J. I. Hussain, A. Y. Obaid, S. A. Al-Thabaiti, and E. H. El-Mossalamy, "Starch-directed green synthesis, characterization and morphology of silver nanoparticles," Colloids and Surfaces B: Biointerfaces, vol. 102, pp. 578-584, 2013.

[61] D. Philip, "Honey mediated green synthesis of gold nanoparticles," Spectrochimica Acta Part A: Molecular and Biomolecular Spectroscopy, vol. 73, no. 4, pp. 650-653, 2009.

[62] H. Haiza, A. Azizan, A. H. Mohidin, and D. S. C. Halin, "Green synthesis of silver nanoparticles using local honey," Nano Hybrids, vol. 4, pp. 87-98, 2013.

[63] S. M. Reddy, K. K. R. Datta, C. Sreelakshmi, M. Eswaramoorthy, and B. V. S. Reddy, "Honey mediated green synthesis of Pd nanoparticles for suzuki coupling and hydrogenation of conjugated olefins," Nanoscience and Nanotechnology Letters, vol. 4, no. 4, pp. 420-425, 2012.

[64] R. Venu, T. S. Ramulu, S. Anandakumar, V. S. Rani, and C. G. Kim, "Bio-directed synthesis of platinum nanoparticles using aqueous honey solutions and their catalytic applications," Colloids and Surfaces A: Physicochemical and Engineering Aspects, vol. 384, no. 1-3, pp. 733-738, 2011.

[65] L. Wu, X. Cai, K. Nelson et al., "A green synthesis of carbon nanoparticles from honey and their use in real-time photoacoustic imaging," Nano Research, vol. 6, no. 5, pp. 312-325, 2013.
[66] N. Vigneshwaran, R. P. Nachane, R. H. Balasubramanya, and P. V. Varadarajan, "A novel one-pot 'green' synthesis of stable silver nanoparticles using soluble starch," Carbohydrate Research, vol. 341, no. 12, pp. 2012-2018, 2006.

[67] M. Honey, J. M. Alvarez-Suarez, M. Gasparrini, and T. Y. Forbes-Herná, "The composition and biological activity of honey: a focus on Manuka honey," Foods, vol. 3, no. 3, pp. 420432, 2014.

[68] V. M. French, R. A. Cooper, and P. C. Molan, "The antibacterial activity of honey against coagulase-negative staphylococci," Journal of Antimicrobial Chemotherapy, vol. 56, no. 1, pp. 228231, 2005.

[69] M. Khalil and S. Sulaiman, "The potential role of honey and its polyphenols in preventing heart disease: a review," African Journal of Traditional, Complementary and Alternative Medicines, vol. 7, no. 4, 2010.

[70] T. Eteraf-Oskouei and M. Najafi, "Traditional and modern uses of natural honey in human diseases: a review," Iranian Journal of Basic Medical Sciences, vol. 16, no. 6, pp. 731-742, 2013.

[71] P. B. Olaitan, O. E. Adeleke, and I. O. Ola, "Honey: a reservoir for microorganisms and an inhibitory agent for microbes," African Health Sciences, vol. 7, no. 3, pp. 159-165, 2007.

[72] M. L. González-Miret, A. Terrab, D. Hernanz, M. Á. FernándezRecamales, and F. J. Heredia, "Multivariate correlation between color and mineral composition of honeys and by their botanical origin," Journal of Agricultural and Food Chemistry, vol. 53, no. 7, pp. 2574-2580, 2005.

[73] J. Tewari and J. Irudayaraj, "Quantification of saccharides in multiple floral honeys using fourier transform infrared microattenuated total reflectance spectroscopy," Journal of Agricultural and Food Chemistry, vol. 52, no. 11, pp. 3237-3243, 2004.

[74] V. León-Ruiz, S. Vera, A. V. González-Porto, and M. P. San Andrés, "Analysis of water-soluble vitamins in honey by isocratic RP-HPLC, Food Analytical Methods, vol. 6, no. 2, pp. 488-496, 2013.

[75] M. Al-Mamary, A. Al-Meeri, and M. Al-Habori, "Antioxidant activities and total phenolics of different types of honey," Nutrition Research, vol. 22, no. 9, pp. 1041-1047, 2002.

[76] V. Nanda, B. C. Sarkar, H. K. Sharma, and A. S. Bawa, "Physicochemical properties and estimation of mineral content in honey produced from different plants in Northern India," Journal of Food Composition and Analysis, vol. 16, no. 5, pp. 613-619, 2003.

[77] A. K. Mittal, Y. Chisti, and U. C. Banerjee, "Synthesis of metallic nanoparticles using plant extracts," Biotechnology Advances, vol. 31, no. 2, pp. 346-356, 2013.

[78] C. Sreelakshmi, K. K. R. Datta, J. S. Yadav, and B. V. Subba Reddy, "Honey derivatized Au and Ag nanoparticles and evaluation of its antimicrobial activity," Journal of Nanoscience and Nanotechnology, vol. 11, no. 8, pp. 6995-7000, 2011.

[79] I. B. Obot, S. A. Umoren, and A. S. Johnson, "Sunlight- mediated synthesis of silver nanoparticles using honey and its promising anticorrosion potentials for mild steel in acidic environments," Journal of Materials and Environmental Science, vol. 4, no. 6, pp. 1013-1018, 2013.

[80] D. Philip, "Honey mediated green synthesis of silver nanoparticles," Spectrochimica Acta Part A: Molecular and Biomolecular Spectroscopy, vol. 75, no. 3, pp. 1078-1081, 2010.

[81] G. P. Luke, A. Bashyam, K. A. Homan, S. Makhija, Y.-S. Chen, and S. Y. Emelianov, "Silica-coated gold nanoplates as stable photoacoustic contrast agents for sentinel lymph node imaging," Nanotechnology, vol. 24, no. 45, Article ID 455101, 2013. 
[82] X. Yang, Y. Zhuo, S. Zhu, Y. Luo, Y. Feng, and Y. Dou, "Novel and green synthesis of high-fluorescent carbon dots originated from honey for sensing and imaging," Biosensors and Bioelectronics, vol. 60, pp. 292-298, 2014. 

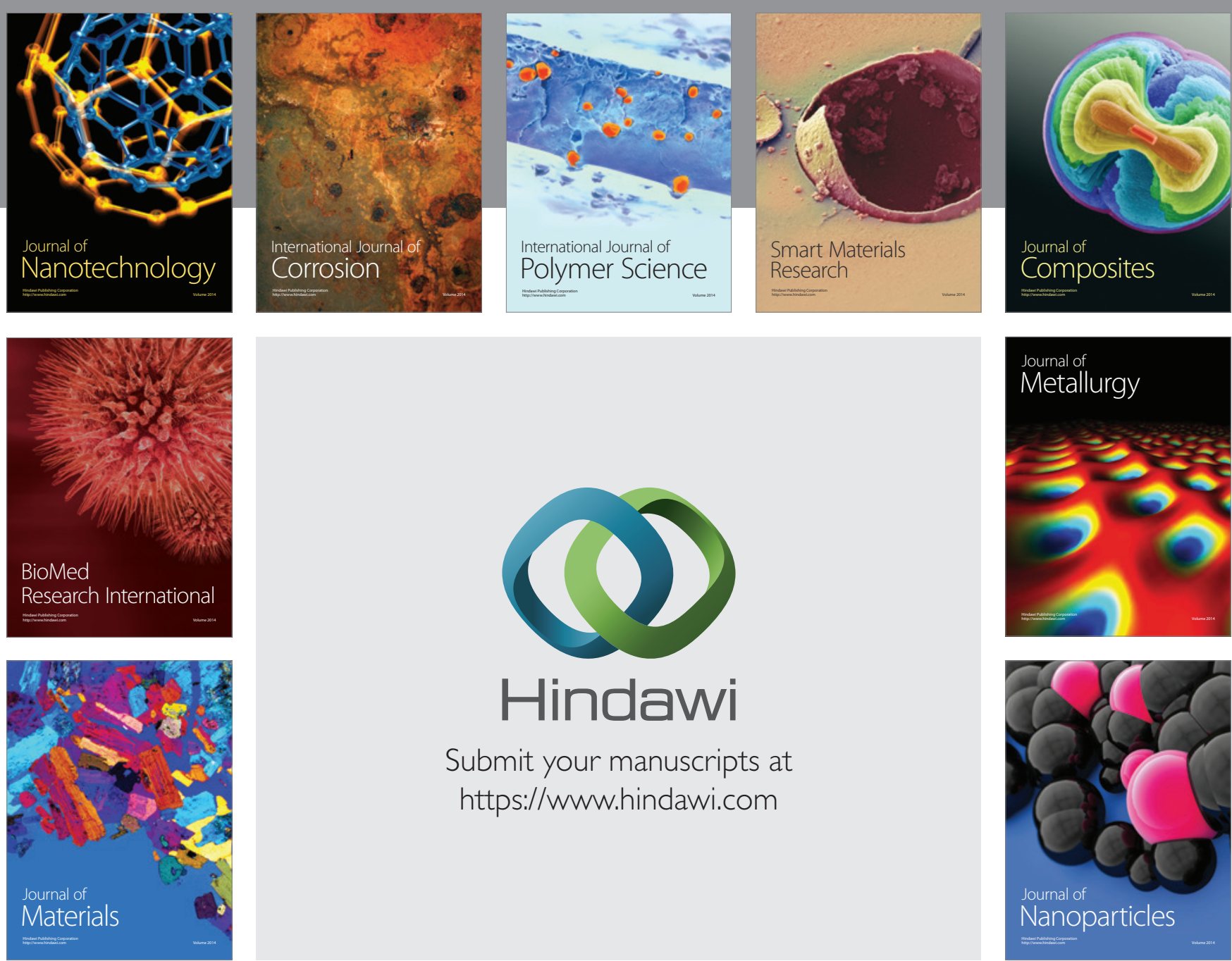

\section{Hindawi}

Submit your manuscripts at

https://www.hindawi.com

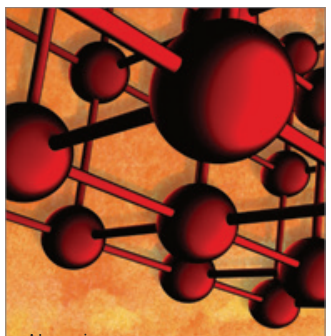

Materials Science and Engineering
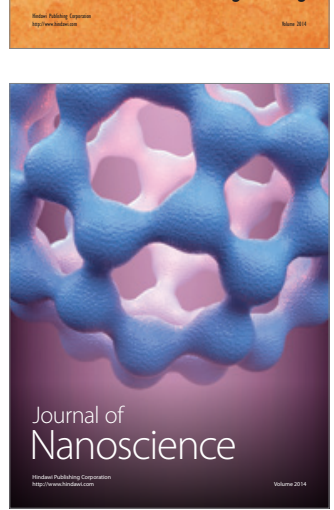
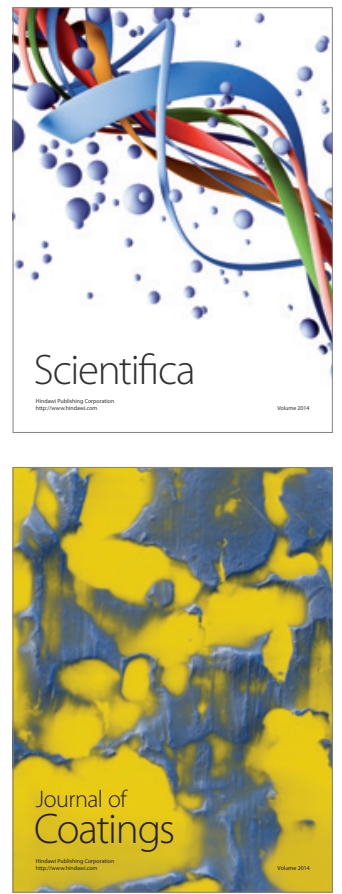
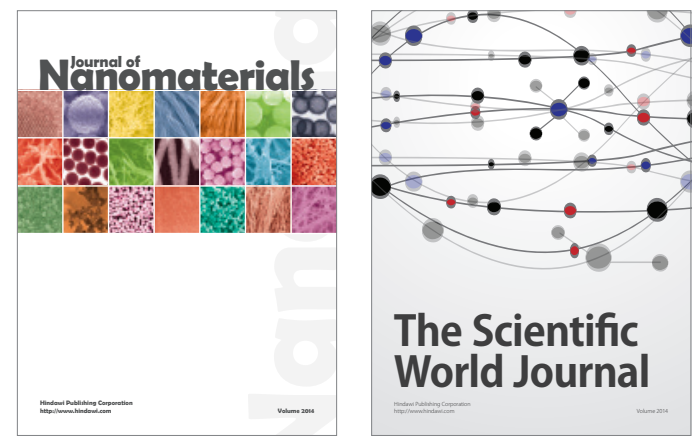

The Scientific World Journal
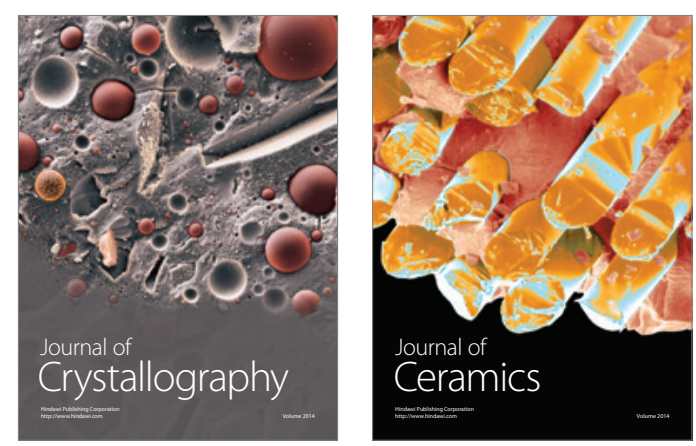
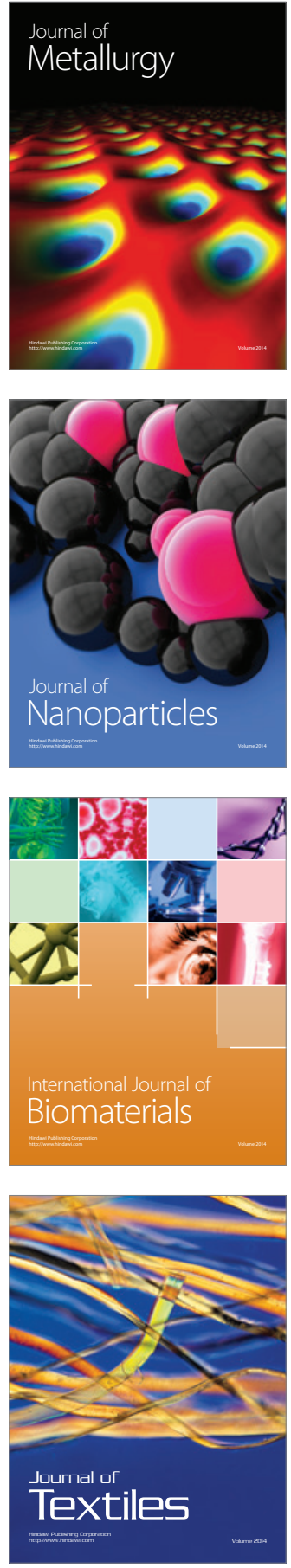